\title{
Autoeficácia e Participação Política
}

\section{Guilherme Azzi Russo}

O que faz alguns indivíduos participarem de movimentos políticos, enquanto outros não se engajam com questões políticas? Por que certos grupos demográficos são mais politicamente ativos? E como as experiências educacionais afetam decisões que levam à participação ou à apatia política?

Neste capítulo, explico como o construto de autoeficácia nos ajuda a responder a essas perguntas, e a entender o processo de decisão que leva algumas pessoas a se engajar mais com política do que outras. Discuto também os mecanismos pelos quais pessoas desenvolvem crenças de autoeficácia política, e o importante papel que a educação tem sobre o que os cidadãos pensam sobre a capacidade de entender os processos políticos e deles participar.

\section{O conceito}

Bandura (1997, p. 3) define autoeficácia como "as crenças de alguém em sua capacidade em organizar e executar cursos de ação requeridos para produzir certas realizações”. De forma mais simples, o conceito pode ser ilustrado pela resposta à seguinte pergunta: "Será que eu consigo realizar a tarefa X?" A resposta para essa pergunta vai depender das percepções que temos sobre a dificuldade da tarefa (a certa realização) em comparação às habilidades que temos para gerenciar as condições para realizar essa tarefa X. Consideremos um exemplo. Se eu perguntasse a você, leitor, se consegue entender um texto em português. Muito provavelmente diria que sim, pois deve crer que possui as habilidades necessárias para realizar essa tarefa - no caso, ter conhecimento da língua portuguesa, saber ler e compreender um texto.

Porém, e se eu lhe perguntasse como consegue entender um texto em português sobre Física Quântica. Agora provavelmente não teria a mesma certeza para responder que sim, ou talvez até tivesse certeza para dizer que não. Perceba que a única coisa que 
Autoeficácia em Contextos de Saúde, Educação e Política

Roberto Tadeu laochite \& Roberta Gurgel Azzi

Organizadores

para continuar lendo, clique aqui 